\title{
USING LiTERATURE CIRCLES FOR IMPROVING EFL LEARNERS' SPEAKING SKILLS
}

\author{
BY \\ Hanaa El-Baz \\ Lecturer of Curriculum \& TEFL \\ Faculty of Education \\ Damietta university
}

DOI: $10.12816 / 0052308$

مجلة الدراسات التريوية والانسانية ـ كلية التربية ـ جامعة دمنهور

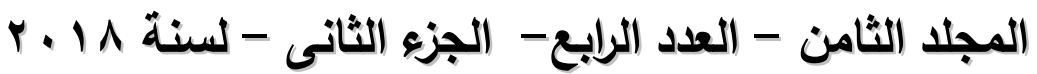




\title{
Using Literature Circles for improving EFL learners' Speaking Skills
}

\section{Hanaa El-Baz}

DOI: $10.12816 / 0052308$

\begin{abstract}
The current study aims at investigating the effectiveness of using literature circles strategy on developing first year secondary stage students' speaking skills. The sample of the study consisted of 80 students enrolled in Kafr Saad secondary School in Damietta. The sample's ages ranged between 15-16 years old. The sample was randomly assigned into two groups, the experimental group (40) and the control group (40). Students of the experimental group received training through literature circles strategy while students in the control group received regular instruction. Instruments of the study included: (a) an EFL speaking checklist to determine the most important speaking skills to be developed for first year secondary stage students, (b) pre-post speaking skills test to measure speaking skills before and after implementing the strategy with a rubric for correction. The researcher taught the experimental group using literature circles strategy for three months (12 sessions, one session per week). A t-test was used to statistically analyze results of the test. Findings of the study revealed that the experimental group students' EFL speaking skills were developed as a result of using literature circles strategy. It is concluded that literature circles strategy is effective in developing first year secondary stage students' speaking skills.
\end{abstract}

Keywords: Literature Circles Strategy, Speaking Skills 


\section{Introduction}

Language is one of the most essential means of communication between communities and individuals. Anyone who wants to convey messages or feelings whether orally or in a written form should use a language. It is known that English language is considered the first international language which is used in all fields as; politics, technology, economy, formal conferences, industry, commerce, tourism, journalism and education.

Teaching speaking skills has become increasingly important in English as a foreign language due to the large number of learners who want to use English spontaneously and freely for communicative purposes. Recently, EFL speaking skill has begun to be taken seriously. Previously, it seemed to be assumed that students would just learn this skill somehow in the general process of learning English as a foreign language. It seemed reasonable to think that the student would acquire this skill while learning to write, read and listen. However, this process does not seem to produce the desired results.

The need for speaking mastery in English has increased due to the strengthening position of English as a language for international communication. It has become apparent that students of English as a foreign language have considered themselves good and successful learners if they can communicate fluently and effectively in English. (Graves, 2008; Nazara, 2011). At present, the ability to speak English fluently has become a must, especially for EFL students. According to Derwing, Rossiter, Munro and Thomson (2004, p. 661) fluency is considered an important characteristic of foreign language speech for a variety of reasons. EFL learners' need to speak fluently ranges from a mere desire to feel confident and secure when talking to others in English, to an urgent need to pass a language test of spoken English.

Teachers should be careful in choosing activities, which are at the level of their students. Harmer (2004 p. 133) declared that teachers should choose activities which the students, at their level, are capable of doing in English while there is nothing wrong in "stretching" them with challenging activities which engage them more; it is clearly counterproductive to set them tasks they are unable to perform.

Richards and Renandya (2005 p. 209) argue that effective interactive activities should be manipulative, involving learners in using English for a variety of communicative purposes. The give-and-take exchanges of messages will enable ESL learners to create discourse that conveys their interactions in real-life communication.

Doi: $10.12816 / 0052308$ 
Many researchers such as Reichert (2005) and Harmer (2001) have suggested that innovative concepts related to teaching speaking replace more traditional ones. Among those innovative strategies is a literature circles strategy. Literature circles are distinctive in that they involve much more than other methods. Literature circles are a form of literary engagement in which students are placed in small groups and encouraged to read with a focus and then report on and discuss what they read, determining for themselves what is significant and why (Daniels, 2002). During discussion, each student undertakes a role that corresponds to specific cognitive task during discussion, thereby providing a support framework for the discussion. The classroom teacher offers help and support to students as they apply strategies while interacting with each other and with the presented material. A long-term goal of this approach is the self-regulated use of these strategies to foster comprehension (Hill, Noe, \& King, 2003). Literature Circles strategy (LC) is a teaching method in which students discuss the presented material at certain intervals in groups (Daniels, 2002).

\subsection{Background and statement of the Problem}

In spite of the importance of speaking skill at the secondary stage, students suffer from weaknesses in their speaking skills. This can be attributed, in the light of the researcher's experience, to the prevailing traditional methods of teaching speaking. Students are rarely required to say more than a few words in response to some 'display' questions raised by the teacher. Moreover, some students lack the speaking skills necessary especially in using correct pronunciation, suitable grammar and vocabulary during speaking in English. They seem to face difficulties in: Speaking fluently without hesitation and undue pauses and adopting natural rate of speech, pronouncing words with the correct stress, pronouncing English consonants correctly in sentences, using appropriate words in different situations, choosing appropriate vocabulary to express the main idea, using appropriate structures and suitable tenses. Moreover, they can't put words together in correct meaningful word order. In addition, they can't exchange information among participants and with teacher without fear or shyness.

Accordingly, the researcher conducted a pilot study to determine how far secondary school students acquire speaking skills to assure that there were problems related to speaking in the Egyptian secondary school. This pilot study test was administered to 50 second year secondary students where five speaking skills were tackled. Results of this piloting test, along with observations of students' performance in exams and some quizzes- that were provided to the researcher through 
students' teachers- revealed that there was a weakness in the speaking skills among secondary stage students.

To come to a closer identification of the problem, a pilot study based on an informal questionnaire was administered to 12 secondary stage English language teachers and supervisors (6 teachers and 6 supervisors). This questionnaire aimed at identifying the methods and techniques currently employed by teachers to develop speaking skills among secondary school students. It was found out that students were not provided with adequate opportunities to practice speaking. Major findings of the questionnaire also revealed that there was no interaction between teachers and students or among students themselves in speaking classes.

Problem of the study was further supported by the results of some previously related studies in the Egyptian context such as the studies of Dorgham (2011), Mohammed (2011), Essa (2011), Hassan (2013) and Ibrahim (2007) which emphasized the fact that EFL speaking skills are inadequate. Thus, all previous studies highlighted the need for adopting better teaching strategies to foster EFL secondary students' speaking skills.

Hence, it is so important to carry out such a study in order to improve students' speaking skills and increase their achievement through using literature circles strategy. Literature circles boost a helpful, responsible, and entertaining classroom environment where students make decisions in accordance with their own needs and interests (Burns, 1998). When students work with peers they improve their listening skills as well and become more authentic with those who make up their interesting learning community. Moreover, literature circles are controlled by students and their own visions and investigations, making classes more significant and authentic.

In the light of reviewing related literature and analyzing results of the pilot study, it could be indicated that the problem of the present study is about the secondary school students' shortage in speaking skills due to the lack of motivation and limited participation in classroom activities. Thus, the present study aims at investigating how literature circles strategy can improve EFL speaking skills among secondary school students.

\subsection{Research Questions}

The present study attempts to answer the following main

To what extent is the proposed strategy effective in developing question: secondary stage students' EFL Speaking skills?

Doi: $10.12816 / 0052308$ 
This question can be divided into the following sub-questions

1.What are the basic EFL Speaking skills required for secondary school students?

2.To what extent do first year secondary school students master such skills?

3.What are the features of a literature circles strategy to develop secondary stage students' EFL Speaking skills?

4.How far is the proposed strategy effective in developing first year secondary school students' EFL Speaking skills?

\section{Review of literature}

The term literature circles is used to refer to an approach that incorporates reading, writing, and discussions in small groups. For instance, four to five students are seated close to one another, talking about a book they are reading, using text to inform, confirm, laugh, argue, and share for purposes that are largely of the students own choosing (Noe \& Johnson, 1999).

Literature circles are also called group meetings in which students are asked to get together to read, recollect, reflect, and analyze the assigned reading materials. The true intent of LC is to allow students to practice and develop the skills and strategies of good readers (Hismanoglu, 2005). They are viewed as a viable means to provide authentic or meaningful reading experiences by engaging students in reading real books (Daniels, 1994, 2002). This engagement is implemented while students are involved in speaking group discussions.

Literature circles are different from other kinds of group discussion; they are distinctive in that they incorporate various learning features in literary instruction. Generally, all literature circles share three basic elements: diversity, self-choice, and student initiation (Lin, 2002). Literature circles combine the principles of cooperative learning and independent reading into a group discussion. Hence, Daniels (2002, p. 18) introduced the characteristics of LCs including the following eleven key elements, each of which adds to the success of LCs. These elements deal, among other things, with: regular meetings of small groups; discussing ideas within prescribed rules; taking notes when necessary; and having the teacher as monitoring facilitator in an enjoyable classroom environment. In addition, Sandman and Gruhler (2007) identify five key features of literature circles which include: student choice, mini-lessons, reading schedules, note-taking skills and assessment.

Flynt and Brozo (2009) point out that literature circles unite the necessary language skills including reading, writing, speaking, and 
listening into one successful package. More than that, literature circles encourage discussion among classmates that may not always be dominant in whole group discussion. Meaningful and deep discussion among students within the classroom is not only valuable for students; it is valuable for the teacher as well. Talk has a large role in the concept of learning and succeeding.

The importance of talk during Literature Circles is reiterated in Short, Kaufman, Kaser, Kahn, \& Crawford (1999). However, the authors in this article don't just observe students' talk but the teachers' role in talk in the Literature Circles. The teachers have to be facilitators, participants, mediators, and active listeners (Short, 1999, 378). As a facilitator, the teacher needs to be able to encourage students' discussion, clarify or provide additional information for students' understanding, restate students' comments to create a deeper understanding for those who may not heard or understood, provide order in the group setting, and to challenge students' comments.

The use of talk in literature circles was shown in Clark (2007). He looked at how power of talk was exemplified based on gender during a literature circle discussion group in a fifth grade classroom. Clark conducted research that focused particularly on one group of students that consisted of two girls and three boys. They were discussing one of the children's novel, Shiloh by Phyllis Reynolds Naylor. The boys showed dominance within the group by not only controlling the discussion, and shutting out the girls, but also by directing the discussion off topic, sparring with words, and calling each other's names. The researcher determined that if used appropriately, Literature Circles are "an important classroom practice and that by participating in effective group discussions both boys and girls can acquire the new basic communication skills required by today's workforce" (p.121).

King (2001) looks at how the use of talk in Literature Circles allows for students to develop a meaningful interaction with texts. The author states that when students are participating in a "small group unstructured expressive talk, they are able to articulate affective responses" (p. 32) that normally would be dormant. By allowing the open discussion of the text, literature circles allow students to make a deeper connection to the text and therefore allow for a deeper understanding. King implements using literature circles with a fifth grade class at the University of Brighton. Just like Short et al (1999), King indicates that the role of the teacher is to teach students how to respond and eventually transfer the control of the discussion to the students.

Doi: $10.12816 / 0052308$ 
There are many roles to be played by the teacher if he decided to use literature circles as a strategy in teaching. Teachers need to organize the groups, and prepare needed material. They also prepare students, engage in group conversations and be ready to answer students' questions. One of the essential roles is to keep a set of teacher's notes concerning positive and negative student behavior, ideas for new roles, roles to reflect on, pronunciation to correct, grammar to explain, and fluency in speaking. Teacher also meets with groups as an observer, or active participant, depending on the needs of each group and collects completed role sheets, reports or reviews. Teacher examines the role sheets to assess individual learning, group learning and progress. At this point, teacher might need to develop modifications or enrichment activities, depending on students' needs. In addition, teacher can adjust schedules depending on both the quality of the work and the ability of group members Daniels, (2002), Robb (2000), O’Brien (2007) and Ferguson and Kern (2012).

Daniels (1994 \& 2002) indicated many Students' roles in literature circle. These roles might be played by individual students within one group or by some or all students within one group. One of the students' roles is to be a discussion director or a questioner. Student who plays this role is asked to promote discussion and ask higher level questions about the presented material. Another role played by students is to be a literary luminary who chooses material to be covered. Vocabulary enricher or word master is an important role for students involved in literature circles strategy. Students choose difficult words from the presented material and explain its meaning to the other members of the group as well as write the pronunciation of the word. The summarizer role is so important and it needs clever student as he summarizes the main points. The connector is another role played by students when using literature circle strategy, the student relates things that occur in the presented material with his life, another text he reads or movie or with the outer world. The illustrator is one of the main roles, his job is to draw a picture related to the presented topic or material. This picture might be a sketch, cartoon, diagram, story-map or a graphic organizer that conveys an important idea or feeling and discuss it with his group. Being an investigator is one of the students' roles in literature circles. In this role, students investigate what interests them in the presented material and discuss it in detail.

Stressing the importance of literature circles strategy in developing speaking skill and other areas of language learning and teaching, some researchers were interested in investigating the 
effectiveness of the strategy. This concern exhibited itself through conducting a number of studies to investigate the effectiveness of Literature circles strategy.

Karatay (2017) utilized the strategy of "literature circles" to improve the text-analysis skills, reading desires, and interests of prospective teachers of Turkish. "Literature circles" was not chosen to be used as the sole strategy throughout the entire weekly class hours; instead, it was used only for one class hour of every weekly four-hour classes, being complementary to and supportive of other teaching activities. Based on the results, it may be concluded that "literature circles" is effective in developing students' abilities to find the theme, main idea, and keywords in a text. Besides, the students pointed out that the implementation of this strategy increased their interest and desire for communication, their self-confidence, cooperative learning, critical thinking, reading objectively without bias, and independent reading skills.

The purpose of Pei's study (2018) was to examine the impact of virtual literature circles (VLCs) on Chinese university (EFL) students' independent English language reading. Univariate analysis revealed that participation in VLCs led to statistically better performance in the reading experience survey and the reading comprehension test. The research provided empirical evidence for the overall effectiveness of the VLC. Findings of the study have important implications for EFL reading instruction and research.

In a longitudinal qualitative study, Clarke (2005) relied upon critical discourse analysis to uncover the multiple layers of influence upon literature circle discussions in order to see beyond the surface of these conversations. By using this analytical lens, the researcher was able to explore the social and cultural practices upon which these discussions were created and sustained. Through the second year, gender and social class were still powerful influences upon students' discussions, but not in the way that had anticipated after completing their first year's study. When following these students in fourth grade, the researcher found that the boys engaged in many more dominating discursive practices that essentially marginalized the girls in this setting. However, when followed the same group of students up to the fifth grade, these gendered interactional patterns have shifted.

Similarly, Briggs (2010) examined the use of literature circles in a third grade class. The research examined students' performance on reading comprehension assessments before and after the use of literature circles. Other evidence of students' learning and engagement with

Doi: $10.12816 / 0052308$ 
reading were examined. This research provides third grade teachers with literature circles activities to support the development of reading comprehension in their students. It is found that through the use of literature circles students developed better comprehension skills while increasing social skills that lead to enriched learning.

Lai (2011) investigated the effects of integrating literature circles into freshmen English classes on cultivating critical thinking skills among adult Taiwanese EFL learners. In addition, that study examined, from the participants' perspective, the influence that literature circles (LC) had on shaping EFL learners' thinking processes. As for results obtained from the qualitative data, growth was found in participants' critical thinking skills in both groups. Furthermore, results of the openended questionnaire indicated that majority of the participants in that study favored literature circles and claimed that literature circles enhanced their language skills such as reading and speaking. More importantly, many participants pointed out that literature circles increased their awareness of critical thinking.

In Alissa' study (2018), that aims at gathering data on the use of literature circles through a teacher survey and teachers interviews, teachers reported that social emotional learning, comprehension, literacy, and vocabulary outcomes were impacted through literature circles. The survey gives an indication that literature circles are not a homogenous practice, but an evolving tool that can be fitted to the needs of students.

Muhamuds's study (2016) aims at developing Faculty of Education EFL prospective teachers' communicative competence and autonomy through using an enrichment program based on process drama and literature circles. The study adopted the quasi-experimental research design. A group of (32) Faculty of Education EFL prospective teachers enrolled in the third year, Department of English was randomly assigned to form only one pre-post test treatment group. The data were collected through an oral communicative competence (OCC) recorded interview, an OCC checklist, and a learner autonomy scale. They were pre-and post-administered to the treatment group before and after teaching the enrichment program. The study results revealed that there was a statistically significant difference at 0.01 between the mean scores of the treatment group in the pre-and the post-administration of the oral communicative competence checklist and the autonomy scale in favor of the post administrations. Findings of the study revealed that the enrichment program had a positive effect on developing Faculty of Education EFL prospective teachers' communicative competence (oral 
components) and autonomy. Consequently, it is highly recommended to adopt the enrichment program to develop oral communicative competence and autonomy at both schools and universities.

Additionally, Avci and Yuksel (2011) examined the effect of literature circles on fourth grade primary students' reading habits and comprehension skills. They also collected the opinions of students and teachers about that strategy. In this study, quantitative (pre-test and post-test) and qualitative (case study) methods were employed together. That study was conducted on 72 students in the fourth grade of a private school in Istanbul. Findings showed that literature circles strategy improved the reading comprehension skills of students who had low level reading comprehension. It was also found out that students liked reading books by performing different tasks, discussing and cooperating with their friends over a period of time.

Finally, the purpose of Anderson's study (2012) was to develop a comprehensive understanding of the effects of the implementation of literature circles in an ELL classroom. Literature circles were implemented each day over a nine-week period. Questionnaires were given to the students before and after the implementation of literature circles. A quasi-experimental study compared the control group to that of the treatment group. Students' perceptions of reading before and after the implementation of literature circles were analyzed through the study of the questionnaires, and standardized test scores were analyzed to monitor whether there was an increase due to the implementation of literature circles. Results of the study indicated that the implementation of literature circles positively affected students' perceptions of reading and improved their standardized reading test scores.

\section{Methodology}

This section presents the experimental part of the study. It provides a description of the participants, hypotheses, instruments and treatment of the study.

\subsection{Participants of the study:}

The sample of the study consists of 80 students enrolled in the first year; from Kafr Saad secondary school in Damietta. The sample's ages range between 15-16 years old. They are randomly assigned into two groups, the experimental group (40) and the control group (40). The experimental group received instruction through using literature circle strategy. On the other hand, the control group received regular instruction. Before experimentation, both groups (control and experimental) were pre-tested using the speaking test and it was statistically treated. The purpose of the pre- test was to make sure that 
both groups were almost of the same level. Moreover, students in the experimental group were informed that the study to be carried out is with the aim of developing their speaking skills. So, they were pleased to take part in the experiment. The researcher taught the experimental group students to make sure that literature circles as a strategy is implemented in a proper way since the regular classroom teacher might have little or no knowledge of this strategy with its underlying theoretical foundations.

\subsection{Hypotheses of the Study}

In the current research, the researchers intended to verify the following hypotheses:

1.There would be no a statistically significant difference between the mean scores of the experimental group and the control one in the pre-test, concerning the overall EFL speaking skills and its subskills.

2.There would be a statistically significant difference between the mean scores of the experimental group and the control one in the post-test concerning overall EFL Speaking skills and its subskills, in favor of the former.

3.There would be a statistically significant difference between the mean scores of the experimental group in the pre-and post-tests concerning overall EFL Speaking skills and its subskills in favor of the latter.

\subsection{Instruments of the study}

In order to carry out the experiment of the current study, the researcher used the following tools:

1: A speaking skills checklist

3: A pre-post speaking test to measure students' speaking skills and a rubric for correction.

\subsubsection{Speaking Skills Checklist:}

\section{The Rationale of the checklist:}

The checklist is designed to determine the most important speaking skills to be developed among first year secondary stage students. It is essential for constructing the pre-post speaking test that is designed in the light of the most important speaking skills determined by the jury members.

\section{Sources of the checklist:}

Items of the checklist are derived from different resources to identify the speaking skills needed for the first year secondary stage. They are taken from: 

A) The directives of the ministry of education in teaching English for secondary stage students.
B) Surveying previous studies related to the development of speaking skills at secondary stage.
C) Reviewing literature concerned with speaking skills

\section{Description of the checklist:}

Speaking skills checklist included (5) speaking sub skills: Fluency (5 items), pronunciation (4 items), vocabulary (4 items), grammar (3 items) and interaction (4 items). This checklist followed four point scales for each item i.e very relevant, relevant, less relevant, and not relevant.

\section{Validity of the checklist:}

The first version of the checklist was submitted to jury members in universities of Damietta, Mansura and Ain Shams to determine the important speaking skills needed for first year secondary stage students. It was also submitted to some EFL senior teachers and supervisor. They were asked to modify, omit or add any other needed skills.

\subsubsection{The pre-post speaking test: Purpose of the speaking test:}

The purpose of the pre-post speaking test is to measure students' speaking skills before and after implementing literature circles strategy. The pre-test is used to assure equivalence of both groups "the experimental and control groups" before implementing the experiment, so any progress achieved by the experimental group could be attributed to using literature circle strategy.

\section{Construction of the speaking test:}

The test is constructed in the light of the following resources:

A) Reviewing related studies on testing EFL speaking skills.

B) Identifying the skills to be measured by the test through results obtained from the speaking skills checklist.

\section{Description of the speaking test:}

The test final version consists of five parts. In part one, students are asked to introduce themselves. In part two, they are asked to react to different situations. In part three, students are asked to show their opinions and attitudes. In part four, they are asked to answer questions based on non-liner discourse. Finally, in part five, students are given some elicitation questions.

\section{Piloting the test:}

Piloting the test aims at the following:

1) Timing the test.

2) Determining simplicity /difficulty of test items and instructions. 
Fifty students are selected for piloting the test. They are randomly selected from Kafr Saad secondary School in Damietta.

\section{Test time:}

A class-period of 40 minutes is estimated to be suitable for the students to answer the test. This time is estimated according to the following formula:

The time taken by the fastest student + The time taken by the slowest student $/ 2$

\section{$\underline{30+50}=40$ minutes 2}

\section{Test Validity:}

The test is submitted to a panel of jury members. They have been asked to evaluate each question in terms of correctness and suitability for the students' levels. The Jury members suggested the following:

A) Making pictures more accurate and clear to students.

B) Increasing the number of topics and choices in fluency part so students feel free to express their opinions easily.

C) Increasing the number of picture cards that students are asked to talk about, so students can freely choose from them which consequently lead to livelier interview.

\section{The Internal Consistent Validity}

To determine the internal consistent validity of the test, the correlation coefficients of each needed sub-speaking skill was computed with the total score of the test as a whole. These correlations and their statistical significance are shown in the following table.

TABLE 1. CORRELATION COEFFICIENT OF EVERY ITEM OF THE SPEAKING SKILLS TEST

\begin{tabular}{|c|c|c|c|}
\hline \multirow{4}{*}{$\begin{array}{c}\text { Speaking } \\
\text { skills }\end{array}$} & Question & $\begin{array}{c}\text { Correlation } \\
\text { coefficient } \\
(\mathbf{r})\end{array}$ & P-value \\
\hline \multirow{5}{*}{ Vocabulary } & Question1 & 0.61 & 0.01 \\
\cline { 2 - 4 } & Question2 & 0.73 & 0.01 \\
\cline { 2 - 4 } & Question3 & 0.65 & 0.01 \\
\cline { 2 - 4 } & Question4 & 0.61 & 0.01 \\
\cline { 2 - 4 } & Question5 & 0.54 & 0.01 \\
\cline { 2 - 4 } & Question6 & 0.48 & 0.01 \\
\hline \multirow{2}{*}{ Pronunciation } & Question1 & 0.74 & 0.01 \\
\hline
\end{tabular}

ะ19 
Using Literature Circles for improving EFL learners

Hanaa El-Baz

\begin{tabular}{|c|c|c|c|}
\hline \multirow{7}{*}{ Fluency } & Question2 & 0.75 & 0.01 \\
\cline { 2 - 4 } & Question3 & 0.64 & 0.01 \\
\cline { 2 - 4 } & Question1 & 0.58 & 0.01 \\
\cline { 2 - 4 } & Question2 & 0.48 & 0.01 \\
\cline { 2 - 4 } & Question3 & 0.72 & 0.01 \\
\hline \multirow{5}{*}{ Interaction } & Question1 & 0.62 & 0.01 \\
\cline { 2 - 4 } & Question2 & 0.76 & 0.01 \\
\cline { 2 - 4 } & Question3 & 0.48 & 0.01 \\
\cline { 2 - 4 } & Question4 & 0.59 & 0.01 \\
\cline { 2 - 4 } & Question5 & 0.56 & 0.01 \\
\hline \multirow{7}{*}{ Grammar } & Question1 & 0.79 & 0.01 \\
\cline { 2 - 4 } & Question2 & 0.85 & 0.01 \\
\cline { 2 - 4 } & Question3 & 0.74 & 0.01 \\
\hline
\end{tabular}

Statistical findings of table (1) indicate that the sub-speaking skills test ranged between $(0.48-0.85)$ which are statistically significant at $(0.05)$ level of confidence. These findings reveal the high internal consistency of the test. Hence, the validity of the pre- post speaking test is proven.

\section{Construct validity}

To estimate the construct validity of the pre-post speaking test, the Pearson product moment correlation was used. The correlation coefficient was calculated between the total score for each speaking level and the total score of the whole test. The correlation and P-value are presented in table 2 . 
مجلة الدراسات التريوية والانسانية ـ كلية التربية ـ جامعة دمنهور ـ المجلد الثامن - العدد الرابع - الجزء الثانى - لسنة 7 ا ـ ب

Table 2. CONSTRUCT VALIDITY OF THE SPEAKING TEST

\begin{tabular}{|r|c|c|}
\hline Speaking skills & $\begin{array}{c}\text { Correlation coefficient } \\
(\mathbf{r})\end{array}$ & P-value \\
\hline Vocabulary & 0.66 & 0.01 \\
\hline Pronunciation & 0.53 & 0.01 \\
\hline Fluency & 0.57 & 0.01 \\
\hline Interaction & 0.74 & 0.01 \\
\hline Grammar & 0.60 & 0.01 \\
\hline
\end{tabular}

As shown in table (2), the correlation coefficients for the five dimensions of the test ranged between $(0.53-0.74)$ and they are all high. The level of significance for the correlation of the Vocabulary, Pronunciation, Fluency, Interaction and Grammar components of the test is 0.01 . Therefore; the speaking test is internally consistent and valid.

\section{Test Reliability:}

It is checked by another rater (supervisor of English). Correlation Coefficient has been computed using Pearson Formula:

$$
\mathrm{RAA}=\frac{2 \mathrm{R} \text {. }}{\mathrm{L}+\mathrm{R}}
$$

Where RAA = Reliability coefficient

$\mathrm{R}=$ Correlation coefficient

The correlation coefficient was (0.87). Therefore, the test is considered reliable for the purpose of the current study.

Reliability of the test

For estimating the reliability of the pre- post speaking test, Cronbach's Alpha Coefficient is used in case of item deletion. Results are shown in the following table:

Table 3. The Reliability CoEFFicient AND INTRINSIC VALIDITY OF THE PRE-POST SPEAKING TEST

\begin{tabular}{|r|c|c|c|}
\hline Study tool & Questions & $\begin{array}{c}\text { Cronbach's } \\
\text { Alpha }\end{array}$ & Intrinsic Validity \\
\hline Speaking test & 20 & 0.74 & 0.86 \\
\hline
\end{tabular}

The previous table shows that the reliability coefficient of the five speaking skills is (0.74) for the whole test. This value can be trusted and it means that the test is reliable. Therefore, the test was formulated 
in its final version. Besides, the intrinsic validity values for the five dimensions of the test is $(0.86)$ for the whole test. These findings reveal the high intrinsic validity of the test which means that there is a high correlation between intrinsic validity and reliability.

\section{Test Instructions:}

Instructions for each part of the test are orally explained for both experimental and control groups. The researcher explains each part of the test and the aim of each part to test students' speaking sub-skills which are: vocabulary, pronunciation, fluency, interaction and grammar.

\section{Test administration:}

After carrying out all modifications recommended by the jury members, the test was pre-administrated to both control and experimental groups. The test was also post-administered to both groups after the experimentation of the suggested strategy on the experimental group. Results showed that experimental group students scored high scores compared to students in the control group.

\section{The Rubric:}

Purpose of the Rubric:

The main purpose of the rubric is to grade participants' answers on the pre-post speaking test to assess their EFL speaking skills.

\section{Description of the Rubric:}

The rubric consists of 5 scales of speaking ability to analyze the speaking skills of the sample after both pre- and post-test administration. The rubric is divided into five parts. Part one deals with Fluency of the speaker. Part two is devoted to pronunciation skills. Part three is concerned with vocabulary. Part four deals with grammar and part five deals with interaction. Students received a rating between "one to five" for their answers. Score one stands for low performance, score five stands for high performance. The speech of the students is recorded analyzed and each sub-skill is given a score. The rubric is used by one of the English supervisors to achieve reliability.

\subsection{Treatment of the study}

The main purpose of the current study is to develop speaking skills of the participants by using proposed sessions based on literature circles. The experiment lasted for three months (12 weeks); where the proposed strategy was scheduled to be taught for 45 minutes within one session per-week. The strategy was taught by the researcher, whereas the control group was taught using the traditional way of instruction by the regular classroom teacher. The average difference between the preand the post- administration of the test is counted for each group and it

Doi: $10.12816 / 0052308$ 
was statistically analyzed. An introductory session was presented to explain orally the importance of speaking skills and a summary of the nature and purpose of the strategy; and to motivate the participants as well.

\subsubsection{The proposed strategy}

In the following section, lights are shed on the proposed strategy, its rationale, aims and objectives and materials used in implementing it. This section also provides a detailed description of the duration of implementing the proposed strategy.

\subsubsection{1.. Rationale of the strategy:}

The rationale for this study is based on using literature circles along with cooperative learning as an underlying basic for this strategy to develop speaking skills of first year secondary stage students. Literature circles strategy is based on the cooperative learning approach because it unites the four language skills including reading, writing, speaking, and listening into one package. According to cooperative learning, students use a variety of learning activities to improve their understanding of the presented content. Each member of the team is responsible not only for learning what is taught but also for helping teammates learn, thus creating an atmosphere of achievement. Students work through the assignment until all group members successfully understand and complete it. In literature circles, students meet in small groups. They gather to discuss a specific content in depth and share personal experiences related to that content, this discussion guides the students to encourage conversation in group for what they have read. Discussion groups encourage students to engage in critical thinking and reflection to understand the meaning with other members. Also, the role-sheet tasks give students opportunity to express themselves and other learners and to facilitate group discussion by giving each student a specific task to complete during textual reading.

\subsubsection{Aims of the strategy}

The aim of using literature circles in the present study is to develop speaking skills for first year secondary stage students in relation to some speaking subskills. After making all modifications suggested by the jury members on the speaking skills checklist, the skills are as follows:

Fluency which consists of the following subskills:

a) Using language easily and smoothly.

b) Speaking as near as possible to native like speed.

c) Speaking naturally without clear pauses, hesitation, repetition or redundancy. 
d) Deciding what to say and how to say it in different contexts and situations.

e) Expressing one's opinions and attitudes on a variety of topics or ideas.

Pronunciation which consists of the following subskills:

c) Using intelligible intonation.

d) Pronouncing words with correct stress.

e) Pronouncing English consonant correctly in sentences.

f) Pronouncing English vowels correctly in sentences.

Vocabulary which consists of the following subskills:

a) Using appropriate words in different contexts.

b) Choosing appropriate vocabulary to express ideas.

c) Using abstract words correctly.

d) Using a variety of words and expressions.

Grammar which consists of the following subs kills:

a) Using appropriate structures and suitable tenses.

b) Putting words together in a correct sentence structure.

c) Using correct forms of words (case, gender, ....... ).

Interaction which consists of the following sub skills:

a)Exchanging information among the participants with each other's and

with teacher without fear or shyness.

b)Performing different communicative functions (apologizing, accepting, refusing and complaining).

c) Initiating, continuing, and finishing conversation.

d) Recognizing the right moment to take a turn.

\subsubsection{Materials and resources}

Materials used for implementing literature circle as a strategy in the present study include authentic activities selected from nine units in Student's English Language Book "Hello 6". The researcher covered all speaking activities focusing on the $5^{\text {th }}$ lesson that is mainly concerned with developing students speaking skills in addition to the three revision units. part of implementing the strategy, the researcher asked students to gather information about related topics -to be discussed later in class- to attract their attention and challenge their potentialities beside giving them material from their syllabus. The nine units covered by the researcher are as follows:

- Famous Egyptians

- Charles Dickens

Doi: $10.12816 / 0052308$ 
- The power of the mind

- City or countryside?

- Robert Louis Stevenson

- Tomorrow's world

- Health and safety

- William Shakespeare

- Amazing people

\subsubsection{Duration of implementing the strategy}

The experiment of the present study lasted for three months (12 weeks). The first week was for introductory session and the preadministration of the speaking test to both experimental and control groups. Teaching the experimental group through using literature circles lasted for ten weeks (9 teaching sessions and one evaluative session). The last week was assigned for the post-administration of the speaking test to both groups. The evaluative session was in the $6^{\text {th }}$ week to estimate some of the students' EFL speaking skills and investigate to what extent using literature circles strategy affects students speaking skills. The experimental group received one period of speaking instruction per week. Every period lasted for 45 minutes. During both the first and the last weeks which were assigned for the pre- and postadministration of the speaking test, the researcher met students during the whole week in their English classes, breaks and free classes to test them. The strategy was implemented by the researcher herself. The introductory session at the beginning of the program was important to help students recognize the importance of speaking skills and understand the mechanism of literature circles as a speaking strategy.

4. Results

In order to verify research hypotheses, The Statistical Package of Social Sciences/Personal Computer (SPSS/PC) version 22 was used for statistical analysis to calculate: (a) the average (mean scores) and standard deviation, and (b) the t-test for paired samples and independent samples to compare between the experimental and control groups before and after the experimental study.

\subsection{Verifying the First Hypothesis}

"There would be no statistically significant differences between the mean scores of the experimental group and the control one in the pre-test, concerning overall EFL Speaking skills and its sub skills".

In order to verify the first hypothesis, a t- test for independent samples was used to compare the mean scores of the two groups on the pre-test. The results of the t- test proved to be statistically consistent 
with the hypothesis. See table 4 which shows the mean scores, standard deviations, $t-$ value and the level of significance of the experimental group and the control group students concerning their overall EFL speaking skills, in the pre assessment.

Table 4. T.Test results of the pre-test, comparing the control and the experimental groups in speaking skills

\begin{tabular}{|c|c|c|c|c|c|c|}
\hline \multirow{2}{*}{ Speaking skills } & \multirow{2}{*}{ Study groups } & \multirow{2}{*}{ Mean } & \multirow{2}{*}{ SD } & \multicolumn{3}{|c|}{ T-test } \\
\hline & & & & T-value & DF & P-value \\
\hline \multirow{2}{*}{ Vocabulary } & Experimental group & 11.90 & 2.13 & \multirow{2}{*}{1.22} & \multirow{2}{*}{78} & \multirow{2}{*}{0.225} \\
\hline & Control group & 12.45 & 1.88 & & & \\
\hline \multirow{2}{*}{ Pronunciation } & Experimental group & 5.58 & 1.43 & \multirow{2}{*}{1.25} & \multirow{2}{*}{78} & \multirow{2}{*}{0.214} \\
\hline & Control group & 6.00 & 1.60 & & & \\
\hline \multirow{2}{*}{ Fluency } & Experimental group & 5.78 & 1.42 & \multirow{2}{*}{0.32} & \multirow{2}{*}{78} & \multirow{2}{*}{0.749} \\
\hline & Control group & 5.88 & 1.36 & & & \\
\hline \multirow{2}{*}{ Interaction } & Experimental group & 8.88 & 2.00 & \multirow{2}{*}{1.34} & \multirow{2}{*}{78} & \multirow{2}{*}{0.184} \\
\hline & Control group & 9.43 & 1.65 & & & \\
\hline \multirow{2}{*}{ Grammar } & Experimental group & 6.03 & 1.61 & \multirow{2}{*}{0.77} & \multirow{2}{*}{78} & \multirow{2}{*}{0.445} \\
\hline & Control group & 5.75 & 1.60 & & & \\
\hline \multirow{2}{*}{ Speaking test } & $\begin{array}{r}\text { Experimental } \\
\text { group }\end{array}$ & 38.15 & 6.42 & \multirow{2}{*}{1.02} & \multirow{2}{*}{78} & \multirow{2}{*}{0.311} \\
\hline & Control group & 39.50 & 5.37 & & & \\
\hline
\end{tabular}

Also, results of the table (4) indicate that there are no differences between the mean scores of the EFL students of the experimental and control groups on the pre administration of the speaking skills. By looking at the " $t$ " values $(1.22,1.25,0,32,1.34$, 0.77 and 1.027), it can be noticed that these values are not statistically significant; which indicates that the students of the two groups had similar levels of speaking skills. This reduces the chance for misleading results of the experiment because if the two groups were not equal, it might have affected the results of the experiment. The following figures illustrate these results. 


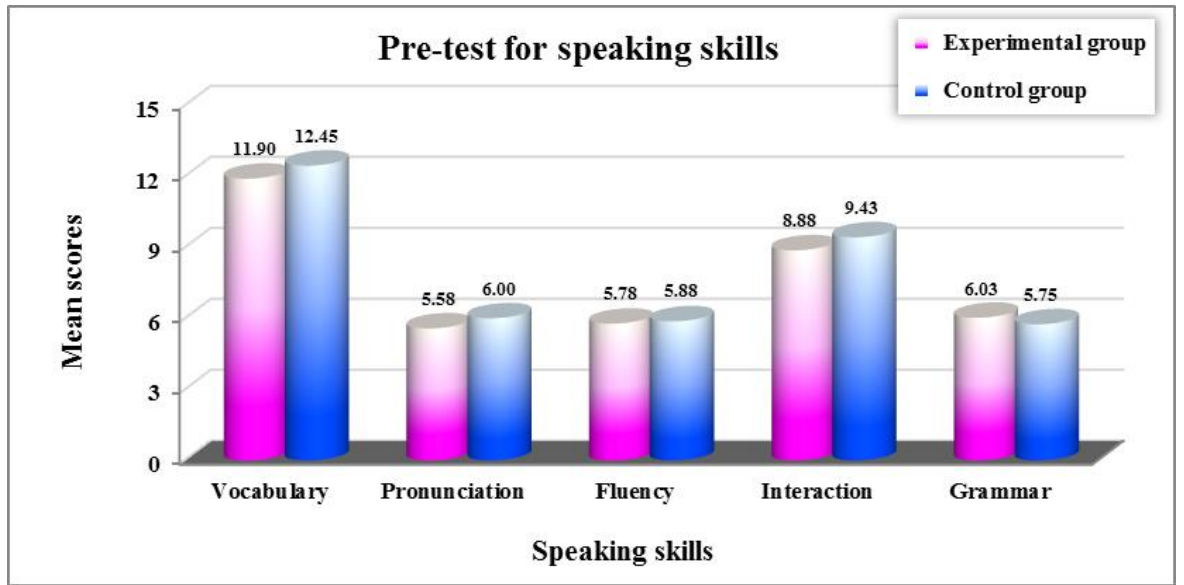

Figure 1. Comparison of the pre- test mean scores of the control and experimental groups in each speaking sub-skill

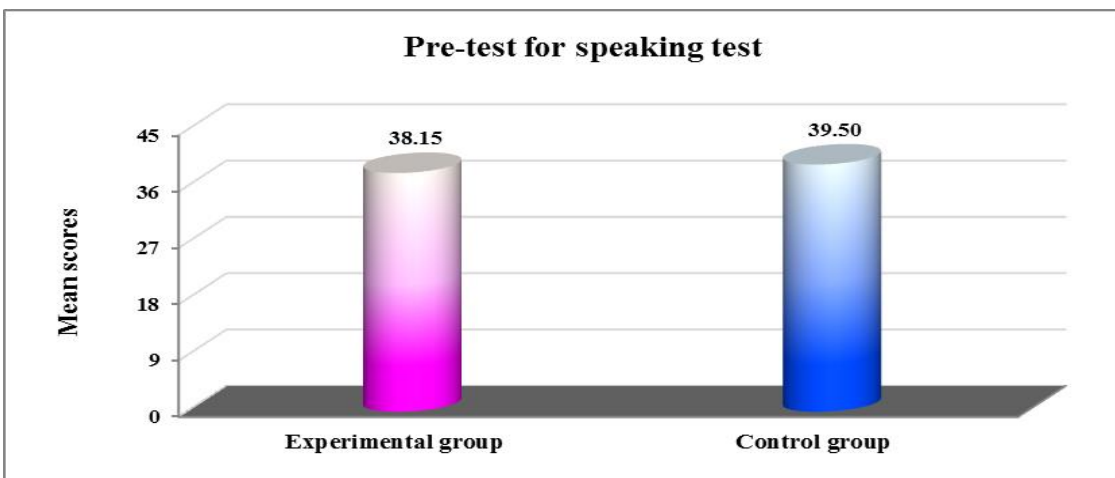

Figure 2. Comparison of the pre- test mean scores of the control and experimental groups in overall speaking skill

4.2. Verifying the Second Hypothesis

"There would be statistically significant differences between the mean scores of the experimental group and the control one in the posttest concerning the overall EFL speaking skill and its sub skills, in favor of the former".

In order to verify the second hypothesis, a t- test for independent samples was used to compare the mean scores of the two groups in the post-test. Results of the t- test proved to be statistically consistent with this hypothesis. See table ( 5 ) which elaborate results related to this hypothesis. 
Table 5. T- Test results of the post- test, comparing the control and the experimental groups in speaking skills

\begin{tabular}{|c|c|c|c|c|c|c|}
\hline \multirow{2}{*}{ Speaking skills } & \multirow{2}{*}{ Study groups } & \multirow{2}{*}{ Mean } & \multirow{2}{*}{ SD } & \multicolumn{3}{|c|}{ T-test } \\
\hline & & & & T-value & DF & P-value \\
\hline \multirow{2}{*}{ Vocabulary } & $\begin{array}{l}\text { Experimental } \\
\text { group }\end{array}$ & 25.73 & 2.09 & \multirow{2}{*}{7.34} & \multirow{2}{*}{78} & \multirow{2}{*}{0.001} \\
\hline & Control group & 21.98 & 2.47 & & & \\
\hline \multirow{2}{*}{ Pronunciation } & $\begin{array}{c}\begin{array}{l}\text { Experimental } \\
\text { group }\end{array} \\
\end{array}$ & 12.10 & 1.30 & \multirow{2}{*}{6.73} & \multirow{2}{*}{78} & \multirow{2}{*}{0.001} \\
\hline & Control group & 9.80 & 1.73 & & & \\
\hline \multirow{2}{*}{ Fluency } & $\begin{array}{l}\text { Experimental } \\
\text { group }\end{array}$ & 11.58 & 2.09 & \multirow{2}{*}{4.66} & \multirow{2}{*}{78} & \multirow{2}{*}{0.001} \\
\hline & Control group & 9.50 & 1.89 & & & \\
\hline \multirow{2}{*}{ Interaction } & $\begin{array}{l}\text { Experimental } \\
\text { group }\end{array}$ & 20.25 & 1.72 & \multirow{2}{*}{7.78} & \multirow{2}{*}{78} & \multirow{2}{*}{0.001} \\
\hline & Control group & 15.93 & 3.07 & & & \\
\hline \multirow{2}{*}{ Grammar } & $\begin{array}{l}\text { Experimental } \\
\text { group } \\
\end{array}$ & 12.33 & 1.33 & \multirow{2}{*}{6.08} & \multirow{2}{*}{78} & \multirow{2}{*}{0.001} \\
\hline & Control group & 9.88 & 2.17 & & & \\
\hline \multirow{2}{*}{ Speaking test } & $\begin{array}{c}\text { Experimental } \\
\text { group }\end{array}$ & 81.98 & 4.31 & \multirow{2}{*}{11.99} & \multirow{2}{*}{78} & \multirow{2}{*}{0.001} \\
\hline & Control group & 67.08 & 6.57 & & & \\
\hline
\end{tabular}

Table (5) reveals that the estimated t values were (7.34), (6.73), (4.66), (7.78) and (6.08) for the following five speaking skills respectively: Vocabulary, pronunciation, fluency, interaction and grammar. These estimated t- values were statistically significant at 0.01 level in favour of the experimental group. Consequently, there was a statistically significant difference at 0.01 level between the mean scores of the control and experimental groups on the post-test in the overall speaking skills $(\mathrm{t}$ value $=\mathbf{1 1 . 9 9}$ ) in favour of the experimental group. Consequently, hypothesis two is verified.

The experimental group students' significant growth in the overall speaking skills test compared to the control group students' performance on the post- test can be illustrated in the following figures. 


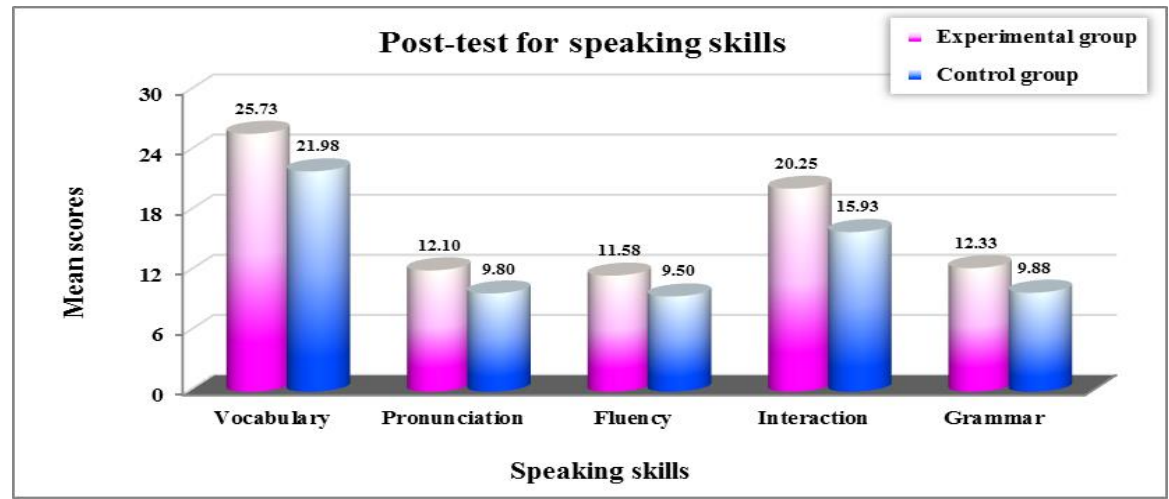

Figure 3. Comparison of the post- test mean scores of the control and experimental groups in each speaking sub-skill

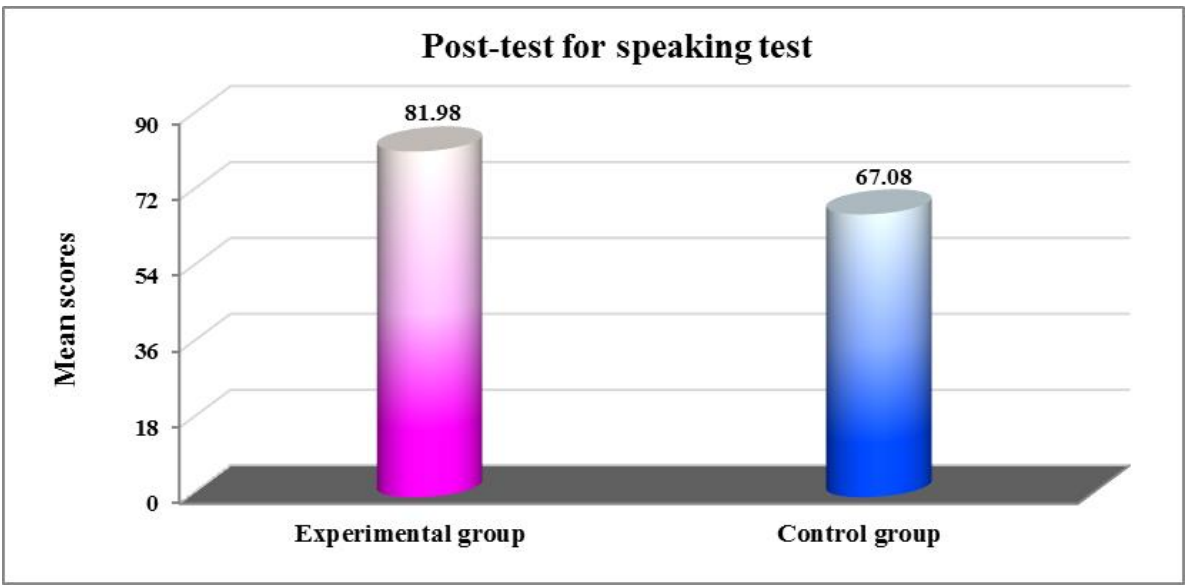

Figure 4. . Comparison of the post- test mean scores of the control and experimental groups in the overall speaking skill

4.3. Verifying the Third Hypothesis

"There would be statistically significant differences between the mean scores of the experimental group in the pre-and post-tests concerning the overall EFL Speaking skill and its sub skills in favor of the latter".

In order to verify the third hypothesis and determine the relative extent of change fostered by the implementation of the proposed strategy from the pre-test to the post-test regarding the experimental group , a paired samples t-test was used. This t-test aimed at comparing the mean scores of the experimental group in the pre- test and the posttest in speaking skills. Results of the t- test proved to be statistically consistent with the hypothesis. For visual representation of the results, see table ( 6 ). 
Table 6. T-test results comparing the pre- test vs. post- test means for the experimental group in speaking skills

\begin{tabular}{|c|c|c|c|c|c|c|}
\hline \multirow{2}{*}{$\begin{array}{c}\text { Speaking } \\
\text { skills }\end{array}$} & \multirow{2}{*}{ Test } & \multirow{2}{*}{ Mean } & \multirow{2}{*}{ SD } & \multicolumn{3}{|c|}{ T-test } \\
\hline & & & & T-value & DF & P-value \\
\hline \multirow{2}{*}{$\begin{array}{c}\text { Vocabular } \\
\mathrm{y}\end{array}$} & Pre-test & 11.90 & 2.13 & \multirow{2}{*}{35.12} & \multirow{2}{*}{39} & \multirow{2}{*}{0.001} \\
\hline & post-test & 25.73 & 2.09 & & & \\
\hline \multirow{2}{*}{$\begin{array}{c}\text { Pronunciati } \\
\text { on }\end{array}$} & Pre-test & 5.58 & 1.43 & \multirow{2}{*}{21.94} & \multirow{2}{*}{39} & \multirow{2}{*}{0.001} \\
\hline & post-test & 12.10 & 1.30 & & & \\
\hline \multirow{2}{*}{ Fluency } & Pre-test & 5.78 & 1.42 & \multirow{2}{*}{16.87} & \multirow{2}{*}{39} & \multirow{2}{*}{0.001} \\
\hline & post-test & 11.58 & 2.09 & & & \\
\hline \multirow{2}{*}{ Interaction } & Pre-test & 8.88 & 2.00 & \multirow{2}{*}{33.18} & \multirow{2}{*}{39} & \multirow{2}{*}{0.001} \\
\hline & post-test & 20.25 & 1.72 & & & \\
\hline \multirow{2}{*}{ Grammar } & Pre-test & 6.03 & 1.61 & \multirow{2}{*}{19.41} & \multirow{2}{*}{39} & \multirow{2}{*}{0.001} \\
\hline & post-test & 12.33 & 1.33 & & & \\
\hline \multirow{2}{*}{$\begin{array}{c}\text { Speaking } \\
\text { test }\end{array}$} & Pre-test & 38.15 & 6.42 & \multirow{2}{*}{44.58} & \multirow{2}{*}{39} & \multirow{2}{*}{0.001} \\
\hline & post-test & 81.98 & 4.31 & & & \\
\hline
\end{tabular}

Table (6) reveals that the estimated t values were (35.12), (21.94), (16.87), (33.18) and (19.41) for the following five Speaking skills respectively: Vocabulary, pronunciation, fluency, interaction and grammar. These estimated t- values were statistically significant at 0.01 level in favour of the post-application of the test. Therefore, there was a statistically significant difference at 0.01 level between the mean scores of the experimental group on the pre-test and the post-test in the overall speaking skill ( $\mathrm{t}$ value $=44.58$ ) and its sub-skills in favor of the postapplication of the test. Consequently, hypothesis three is verified.

The following figures illustrate the experimental group students' significant growth in the overall speaking skill and its sub-skills after the strategy application as compared to their performance on the pretest: 


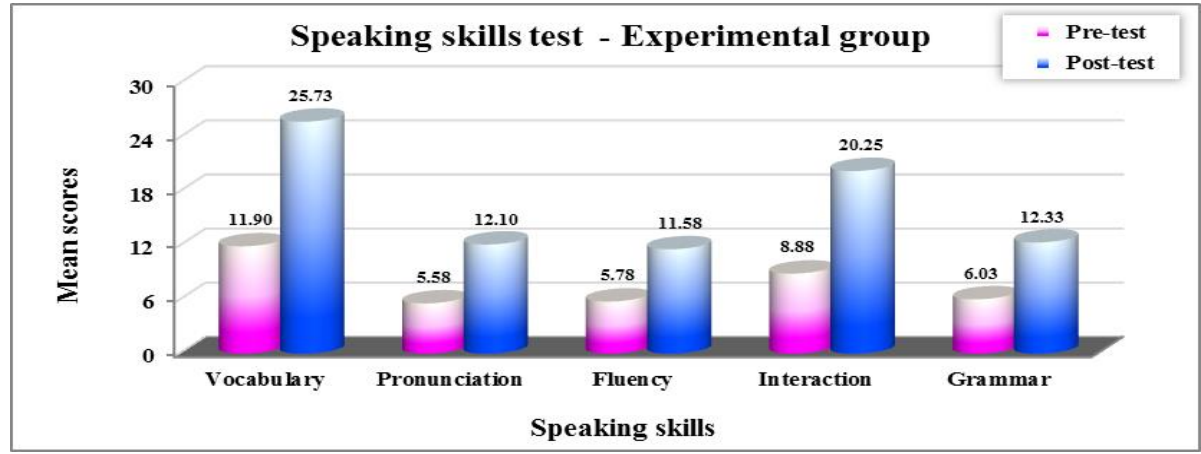

Figure 5. Comparison of the pre- test vs. post- test means for the experimental group in each speaking sub-skills

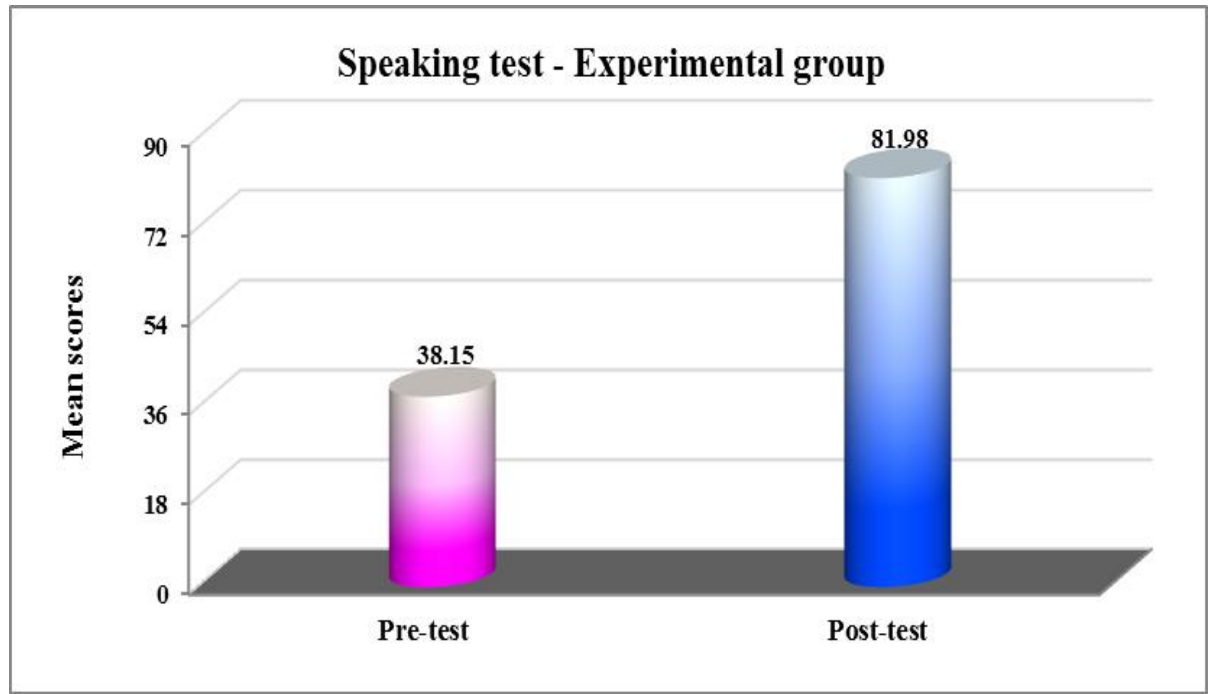

Figure 6. Comparison of the pre- test vs. post- test means for the experimental group in the overall speaking skill

To sum up, support was gained for the three hypotheses of the study. The experimental group out-performed the control group on the post-test in the overall speaking skill performance and in each speaking sub-skill separately. Furthermore, the experimental group students achieved tangible progress in their speaking after the implementation of the strategy as compared to their speaking before the strategy application. Hence, these positive findings of the study proved the effectiveness of using literature circles strategy in developing first year secondary school students' speaking skill.

\subsection{The effect strength of the treatment}

In order to make sure that results obtained from the $\mathrm{t}$ - test were reliable; and to measure the effectiveness of the strategy on students' 
speaking skills, its effect size on students' speaking skills was calculated according to the following formula as suggested by Dunlap (1994):

$$
\begin{gathered}
\mathbf{t}^{2} \\
\eta^{2}= \\
t^{2}+d f
\end{gathered}
$$

" $\eta$ " is the total effect size of the strategy.

" $t$ " is the value of $t$-test.

"d.f" is the degree of freedom.

Effect sizes can be of any magnitude. Effect sizes less than or equal to 0.20 are generally viewed as small, effect sizes equal to 0.50 are generally interpreted as having medium effects, and effect sizes greater than or equal to 0.80 are considered large (Cohen, 1988).

Becker (2000, p.3) states that the referential frameworks for interpreting the effect size value could be as follows:

Table 7. Interpretation of the Effect Size

\begin{tabular}{|c|c|}
\hline EFFECT SIZE & INTERPRETATION \\
\hline From 0.2 to less than 0.5 & Small \\
\hline From 0.5 to less than 0.8 & Medium \\
\hline 0.8 or more & Large \\
\hline
\end{tabular}

Table 8. The effect strength of the treatment ( $\boldsymbol{\eta}^{2}$ value) for the overall speaking skill and its sub-skills

\begin{tabular}{|r|c|c|c|}
\hline Speaking skills & DF & T-value & Eta square \\
\hline Vocabulary & 39 & 35.12 & 0.97 \\
\hline Pronunciation & 39 & 21.94 & 0.93 \\
\hline Fluency & 39 & 16.87 & 0.88 \\
\hline Interaction & 39 & 33.18 & 0.97 \\
\hline Grammar & 39 & 19.41 & 0.91 \\
\hline Speaking test & $\mathbf{3 9}$ & $\mathbf{4 4 . 5 8}$ & $\mathbf{0 . 9 8}$ \\
\hline
\end{tabular}

As shown in table (8), the calculated effect size value of the proposed strategy on the experimental group students' overall speaking was (0.98). This value refers to the fact that the effect size of the independent variable (Literature Circles) on the dependent variable (speaking skills) was great; and this led to improving students' scores 
after administering the strategy. Therefore, it can be said that the proposed strategy had a large effect on the experimental group students' overall speaking skills in the post-test as compared to that of the control group students who received regular instruction.

Figure 7 illustrates the effectiveness of using literature circles in improving secondary stage students' English speaking skills. It shows the $\left(\boldsymbol{\eta}^{2}\right)$ value of the overall speaking skill in a visual form.

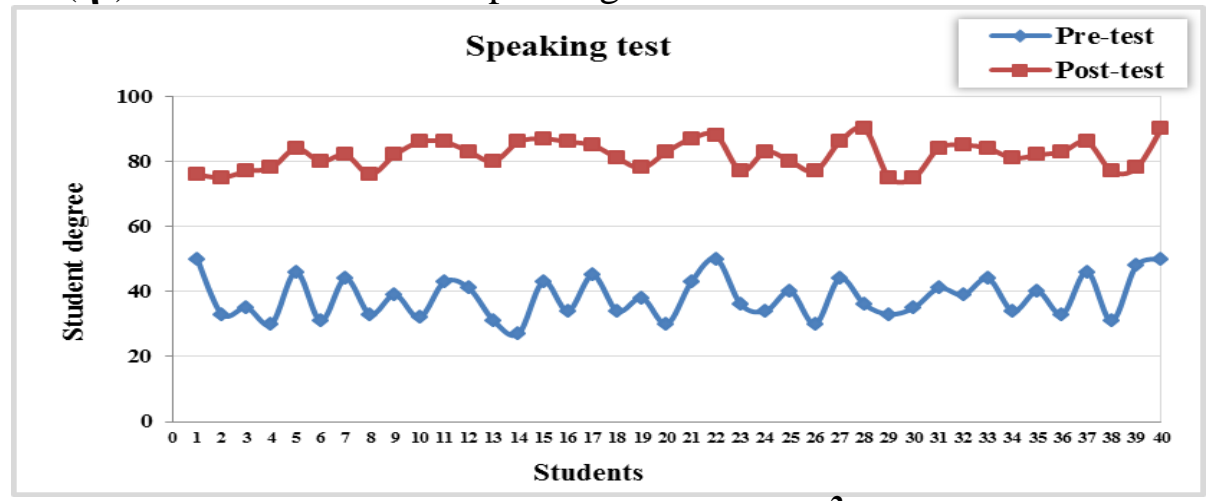

Figure 7. The effect strength of the treatment ( $\boldsymbol{\eta}^{2}$ value) for the overall

\section{Discussion and Conclusion} speaking skill and its sub-skills

The main purpose of the present study was to develop EFL speaking skills for secondary stage students through literature circles using a variety of activities that were offered to the experimental group. Findings showed that the experimental group students have improved their FL speaking skills more than the control group students in the post application of the EFL speaking test compared to the pre-test. This progress is caused by the effect of using literature circles strategy. This proves that literature circles are statistically and educationally significant in developing student's speaking skills. Thus, in the light of the post- test results of the present study, the researcher could safely say that the implemented strategy was effective and accounted for some factors that might have helped the experimental group's progress in the overall speaking skill and its sub-skills.

One of the factors that lead to the success of literature circle strategy in developing secondary stage students speaking skills is the fact that this strategy was mainly dependent on integrations. The integration and interaction between discussion, speaking and literature circles improved students' speaking skills. The integration among the four language skills within the communicative approach is one of the main reasons that lead to the success of this strategy. Accordingly, students participated in interactive literature circles while 
comprehending the presented material. Besides, every group member had a literature circle role or responsibility to do. All students were trained to use each speaking skill properly, and were allowed to discuss and share ideas; they were able to understand presented material successfully. As a result, students start to think on a deeper level about what they are talking and share their thoughts, feelings, and questions in a non-threatening atmosphere.

The second factor that might have been responsible for developing the participants' speaking skills can be attributed to literature circle role tasks; which could be said to be the most important element in enhancing students' speaking skills. Each role had a clear description of the tasks that students were expected to do. In that sense, it could be said that results related to this factor are consistent with the results of other studies such as the studies of Daniels, (2002), Robb (2000), O'Brien (2007) and Ferguson and Kern (2012).

In this context, it is important to indicate that group meetings, natural conversation about presented material and rotation of roles allowed the students to make choices about their learning. The researcher did not assign roles for the students and left this matter for the students themselves to do. In the sense that each one chose the role he/she saw fit. The members of each group exchanged the roles they undertook before, the discussion leader became a summarizer, and the word master became a connector, and so on. Eventually at the end, all members were able to practise all roles. Thus, a choice led students to get engaged deeply in the task, taught them self-reliance, and gave them an opportunity for guided-decision making. Results related to this dimension cope with the study of Peralta-Nash and Duch (2000), Noll (1994) and Burns (1998).

Hence, it is clear from the discussion so far, that the proposed literature circles strategy was valuable in developing secondary stage students' speaking skills. Results reported in the current study coincide with those of previous studies such as Brown (2002), Avci and Yuksel (2011), Anderson (2012), Hamilton (2013), Lai (2011), Maraccini (2011), Marshall (2006), Medrano (2013), Tugman (2010), Wilfong's (2009), which confirm the efficacy of literature circles strategy in developing different aspects of language learning.

This study also brought upon the ideals of effective communication. According to Roberts and Billing (2009), " teachers sometimes forget that learning to communicate is learning to think and like writing, conversation requires constant and ongoing practice" (pp.23 ). Literature circles strategy is an instructional process that teachers can

Doi: $10.12816 / 0052308$ 
use to promote operative learning through conversations that teach students to become active listeners and speakers. According to Roberts \& Billings (2009), the ultimate goal in our global environment is "being able to communicate successfully as the key to employment, to citizenship, and a quality life" (p.1).

Based on the results of the present study, a persistent recommendation needs to be put into consideration when teaching speaking. It is highly suggested that, curriculum designers, decision makers at the ministry of education, professors at colleges of education, and EFL educators, have to reconsider textbooks, programs, and classroom practices in the light of the importance of literature circles as elaborated in the present study. Also, further research may be suggested to be conducted to investigate the effectiveness of using literature circles, in various levels of EFL classes, for developing other language skills, items and/or aspects.

\section{Recommendations:}

Based on the findings of the present study, the following recommendations are suggested:

1. Literature circles strategy should be implemented in teaching EFL speaking skills.

2. More attention should be paid to improve EFL speaking skills and certain courses should be taught in order to enhance students' speaking skills.

3. EFL university instructors should encourage their students to apply literature circles strategy in their micro-teaching sessions.

4. EFL university instructors should clarify the importance of EFL speaking fluency skills to their students. Besides, they should illustrate the importance of literature circles strategy as it offers chances to keep up with the recent EFL approaches.

\section{Suggestions for Further Research:}

Within the delimitations and findings of the present study, the following topics are suggested for further research:

1.An investigation of the effectiveness of the multimedia-based program in developing EFL speaking skills and reducing anxiety in preparatory and secondary levels.

2.An investigation of the effectiveness of the literature circles strategy in developing EFL listening skills.

3.An investigation of the effectiveness of the literature circles strategy in developing EFL reading skills.

4.An investigation of the effectiveness of the literature circles strategy in developing EFL writing skills. 
5.An investigation of the effectiveness of new methods and approaches in developing EFL speaking fluency skills. 


\section{References}

1.Abdel Mageed,M. (2018). The Effect of Using a Program Based on English Digital Stories on Enhancing First-Year College Students' Speaking Skills At Zewail University of Science and Technology. Unpublished M.A Thesis.Faculty of Education. Ain-Shams University University.

2.Alissa, A. (2018). Implementation of Literature Circles in Oregon Middle Schools. Bachelor of Science in University Honors and Science. Portland

StateUniversity. Availableat: https://pdxscholar.library.pdx.edu/cgi/vie wcontent.cgi?article $=1781 \&$ contexthonorstheses

3.Anderson,A.R.(2012). Implementing Literature Circles: An Experimental Study In An English language Learners 'Classroom. Doctor of Philosophy, School of Education, Capella University. Retreived July 8,2014 from: ProQuest Dissertation and Theses Database (UMI No. 3523558).

4.Avci, S., \& Yuksel, A. (2011). Cognitive and Affective Contributions of the Literature Circles Method on the Acquisition of Reading Habits and Comprehension Skills in Primary Level Students. Educational Sciences: Theory and Practice, 11(3), 1295-1300. DOI: 10.1080/19388070902947352.

5.Briggs,S.R.(2010). Using Literature Circles to Increase Reading Comprehension in Third Grade Elementary Students. Master of Science in Education, School of Education and Counseling Psychology, Dominican University of California. Available at:http://eric.ed.gov/?id=ED511091.

6.Burns, B. (1998). Changing the classroom climate with literature circles. Journal of Adolescent \& Adult Literacy: Navigating New Literacies, 42, 124-129. Retrieved on June 25, 2014 from Academic Search Premier database.

7.Clark, L.W. (2007). Discussing Shiloh: A conversation beyond the book. Journal of Adolescent \& Adult Literacy 51(2), 112-122. doi:10.1598/JAAL.51.2.3

8.Clarke, L. (2005). Conversation beyond the Text: The Influence of Gender and Social class on Literature circle discussion. Ph.D Thesis, University of Cincinnati.

9.Clarke, L. (2006). Power through voicing others: girls' Positioning of Boys in Literature circles Discussions. Journal of literary Research, 38 (1), 53-79.

10.Cohen, J. (1988). Statistical power analysis for the behavioral sciences (2nd edition). Hillsdale, NJ: Lawrence Erlbaum Associates.

11.Daniels, H. (1994). Literature circles: Voice and choice in the studentcentered classroom. York, ME: Stenhouse.

12.Daniels, H. (2002). Literature circles: Voice and choice in book clubs reading groups. Portland, ME: Stenhouse. 
13.Derwing, T., Muray, J., \& Thomson, R. I. (2008). A longitudinal study on ESL learners' fluency and comprehensibility development. Applied Linguistics, 29(3), 359-380.

14.Dorgham, R. (2011). The Effectiveness of a Proposed Program in Developing Speaking Skills among preparatory stage Pupils In the Light Of Multiple Intelligence Theory. Unpublished Ph.D. Institute of Educational Studies. Cairo University.

15.Dunlap, W. P. (1994). Generalizing the common language effect size indicator to bivariate normal correlations. Psychological Bulletin, 116, 509-511. Google Scholar

16.El Fadle, E.(2017).The Effect of Content-Based Instruction Program on Developing Some English Speaking skills for Tourism \& Hotels Students. Unpublished M.A Thesis.Faculty of Education. Ain-Shams University University.

17.Essa, S (2011).The Effectiveness of Using a program Based on Storytelling Strategy in Developing Prospective Teachers' oral language Performance Skills. Ph.D. Faculty of Education, Mansura University.

18.Ferguson, L. \& Kern, D. (2012) Re-visioning literature circles: Incorporating comprehension strategy instruction in student-led discussions. The NERA Journal, 47 (2), 23-30.

19.Flynt, E.S., \& Brozo, W.G. (2009). It's all about the teacher. The Reading Teacher, 62(6), 536-538.

20.Graves, K. (2008). The language curriculum: A social contextual perspective. Language Teaching, 41(2), 147-181.

21.Hamer, J (2004). The practice of English language, 3rd ed. Teaching. Longman.

http://www.learningdesigns.uow.edu.au/guides/info/G1/index.htm

22.Hamilton , T. (2013). An Exploration of the Influences of Literature Circles on Secondary Student Reading. Doctor of Education, Faculty of

LindenwoodUniversity.http://gradworks.umi.com/36/01/3601189.html

23.Harmer, J. (2001). The practice of English language teaching,3rd edition, Pearson Education Limited, England: Essex.

24.Hill, B., Noe, K., \& King, J. (2003). Literature circles in the middle school: One teacher's journey. Norwood, MA: Christopher-Gordon Publishers.

25.Hismanoglu, M (2005). Teaching English through Literature. Journal of Language and Linguistic Studies, 1(1), 53-66. Retrieved 22nd.October,

2014,fromhttp://www.jlls.org/issues/volume1/No.1/murathimanoglu.p d.

Doi: $10.12816 / 0052308$ 
26.Ibrahim, D.(2007). The Effectiveness of some Cooperative Learning strategies in Developing Preparatory school Students' English Speaking Skill. Unpublished M.A Thesis.Faculty of Education. Zagazig University.

27.Khalaf, M.(2017). The Effectiveness of Using a Suggested Program Based on WebQuests and Multiple Intelligences Theory in Developing Secondary Stage Students' English Listening and Speaking Skills. Ph.D. Faculty of Education, Assiut University.

28.Karatay, H. (2017). The Effect of Literature Circles on Text Analysis and Reading Desire. International Journal of Higher Education. Vol. 6, No. 5, 66-75 Retrieved on May 5, 2018 from https://files.eric.ed.gov/fulltext/EJ1155611.pdf

29.King, C. (2001). I Like Group Reading because we can share ideas: The role of talk within the literature circle. Reading, 35 (1), 32-36.

30.Lai,C.F.(2011). Cultivating Critical Thinking through Integrating Literature Circles into EFL Freshman English Classes. Master of Arts, Faculty of the Department of Foreign Languages and Literature ,Tunghai University. Available at: http://thuir.thu.edu.tw/handle/310901/10965?locale=en-US.

31.Lin, C. (2002). Literature Circles. Eric Digest. Retrieved September 3, 2015, from http://www.eric.ed.gov.

32.Maraccini, B. J.(2011). Teacher Perceptions of the Use of Literature Circles and Student Engagement in Reading. Doctor of Education, Piedmont College School of Education, Florida Atlantic University. Available at: http://gradworks.umi.com/35/18/3518832.html.

33.Marshall,J.C.(2006). The Effects of Participation in Literature Circles on Reading Comprehension. Doctor of Philosophy, University of Miami, Coral Gables, Florida. Retreived July10, 2014 from: ProQuest Dissertation and Theses Database

34.Mccall, A. (2010). Teaching powerful social studies ideas through literature circles. The Social Studies, 101, 152-159.

35.Medrano, E. D. (2013). An Investigation of Literature Circles as a Means to Promote Reading Comprehension. Doctor OF Philosophy, Faculty of Texas Tech University. Available at: https://repositories.tdl.org/ttuir/handle/2346/50624.

36.Mohammed, A. (2011). Developing Some Speaking Skills in EFL among Secondary Stage Students via Multimedia. An Unpublished M.A Thesis. Faculty of Education.Zagazig University.

37.Muhammed,N. (2016). An Enrichment Program Based on Process Drama and Literature Circles to Develop the Faculty of Education EFL Prospective Teachers' Communicative Competence and Autonomy. Unpublished M.A Thesis.Faculty of Education. Zagazig University.

38.Nazara, T. (2011). Students' perception on EFL speaking skill development. Journal of English Teaching, 1(1), 28-42. 
39.Noe, K. L. S., \& Johnson, N. J. (1999). Getting Started With Literature Circles. Norwood, Massachusetts: Christopher-Gordon Publishers.

40.O'Brien, C. (2007). Using collaborative reading groups to accommodate diverse learning and behavior needs in the general education classroom. Beyond Behavior, 16 (3), 7-15.

41.Pei, L. (2018). Impact oF Virtual Literature Circles On Chinese University EFL Students' Independent English Reading. Doctor oF Philosophy, Oakland University Rochester, Michigan. Available at: https://our.oakland.edu/bitstream/handle/10323/4654/Pei_Dissertation _PDF.pdf?sequence $=1 \&$ isAllowed $=\mathrm{y}$

42.Peralta - Nash, C. \& Dutch, J.A. (2000). Literature circles: Creating an environment for choice. Primary Voices K-6-, 8 (4), 29-27.

43.Reichert, R. (2005). Scientific Discovery Learning with Computer Simulations of Conceptual Domains of learning. Reviewed from www.elearning-reviews.org/publications/270 HTML

44. Richards, J and Renandya, W. (2005). Methodology in language teaching, 6th ed. Cambridge University Press.

45.Robb, L. (2000). Teaching reading in middle school: A strategic approach to teaching reading that improves comprehension and thinking. New York: Scholastic Professional Books.

46.Roberts, T., \& Billings, L. (2009). Speak up and listen. Paideia, 1-6.

47.Sandmann, A., \& Gruhler, D. (2007). Reading is thinking. International Journal of Learning, 13(10; 10), 105-113. Retrieved from http://search.ebscohost.com/login.aspx?direct=true \&db=ehh\&AN=249 53882\&site $=$ e host-live.

48.Tugman,H.(2010).Literature Discussion Groups And Reading Comprehension. Masters in Arts in Education, Northern Michigan University. Available at:https://www.nmu.edu/sites/DrupalEducation/files/UserFiles/Files/Pr eDrupal/SiteSections/Students/GradPapers/Projects/Tugman_Holly MP.pdf

49.Wilfong, L. G. (2009). Textmasters: Bringing literature circles to textbook reading across the curriculum. Journal of Adolescent \& Adult Literacy, 53(2), 164-171.

50.Zaborowski, A.(2014). The Role of Talk in Literature Circles. Master of Science in Education. The College at Brockport: State University of New York. 